\title{
PELATIHAN APLIKASI CANVA DALAM MENDUKUNG PELAJARAN JARAK JAUH BAGI GURU SMK MUHAMMADIYAH 7 JAKARTA
}

\author{
Estu Sinduningrum ${ }^{1)}$, Isa Faqihuddin Hanif'), Rosalina'), Nunik Pratiwi'), Muchammad Sholeh ${ }^{2)}$ \\ 1)Program Studi Teknik Informatika, Fakultas Teknik, Universitas Muhammadiyah Prof Dr.Hamka, Indonesia \\ 2) Program Studi Teknik Elektro, Fakultas Teknik, Universitas Muhammadiyah Prof Dr.Hamka, Indonesia \\ Corresponding author : Estu Sinduningrum \\ E-mail : estu.ningrum@uhamka.ac.id
}

Diterima 09 Oktober 2021, Direvisi 25 Oktober 2021, Disetujui 25 Oktober 2021

\begin{abstract}
ABSTRAK
Pandemi covid-19 sekarang ini sangat berdampak besar disegala aspek kehidupan, tidak terkecuali bidang pendidikan, pelajaran secara keseluruhan dengan cara tatap muka dikehidupan normal, dituntut merubah metode pembelajaran, yaitu pembelajaran jarak jauh (PJJ), perubahan ini menuntut pengajaran (guru) untuk mempu menyesuaikan dengan kebutuhan pengajaran yang lebih menarik dan dinamis. SMK 7 Muhammadiyah Jakarta membutuhkan metode pembelajaran tersebut, oleh karena itu tim pengabdian masyarakat dari fakultas teknik uhamka mengadakan pelatihan penggunaan aplikasi canva desaign grafis untuk mendesai beberapa hal secara mudah. Tujuan dari pengabdian ini yaitu pelatihan pengunaan aplikasi canva berbagai materi pembelajaran dengan visualisasi yang mewakili isi pembelajaran itu sendiri, serta dapat meningkatkan keterampilan guru dalam berkreasi. Hasil pelatihan diadakan selama dua hari, metode praktik dengan media daring, kemudian kuesioner bermetode skala likert dilakukan untuk didapatkan timbal balik atau tanggapan mengenai pelatihan ini, dan ternyata didapatkan bahwa pengetahuan bertambah dengan adanya kegiatan ini sebesar $78,57 \%$ dengan total kepuasaan secara keseluruhan $85,71 \%$.
\end{abstract}

Kata kunci: pelatihan jarak jauh; pelatihan canva; guru SMK Muhammadiyah

\begin{abstract}
The current covid-19 pandemic has had a major impact on all aspects of life, including the field of education, the whole lesson is face-to-face in normal life, it is required to change the learning method, namely distance learning (PJJ), this change requires teaching (teachers) to be able to adapt to the needs of a more interesting and dynamic teaching. SMK 7 Muhammadiyah Jakarta requires this learning method, therefore the community service team from the Uhamka Faculty of Engineering held training on using the Canva Graphic Design application to design several things easily. The purpose of this service is to train the use of the Canva application for various learning materials with visualizations that represent the content of the learning itself, and to improve teacher skills in being creative. The results of the training were held for two days, the practical method with online media, then a questionnaire using the Likert scale method was carried out to obtain feedback or responses about this training, and it was found that knowledge increased by this activity by $78.57 \%$ with a total overall satisfaction of $85,71 \%$.
\end{abstract}

Keywords: canva training; distance training; muhammadiyah vocational school teacher

\section{PENDAHULUAN}

Muhammadiyah merupakan organisasi terbesar di Indonesia dan gerakan dakwahnya sangatlah populer. Tidak hanya pimpinan Muhammadiyah saja yang memiliki tanggung jawab moral, intelektual serta sosial, akan tetapi seluruh kader Muhammadiyah dari Sabang ke Merauke. Bidang pendidikan merupakan salah satu jalur dakwah yang ditekuni oleh Muhammadiyah, ada beragam pendidikan yang dinaungi oleh Muhammadiyah, dari mulai level pendidikan terendah, yaitu taman kanak-kanak, sekolah dasar, sekolah menengah pertama, sekolah menengah atas, sampai ke universitas Hasan et al (2020).
Sesuai dengan UU tahun 2003, nomor 20 untuk pengertian PJJ, yaitu Pembelajaran Jarak Jauh, dalam pasal 1 dari Sistem Pendidikan Nasional, yang menyatakan bahwa PJJ merupakan cara mendidik dimana hadirin murid terpisah dari guru, dan cara belajar dengan menggunakan sumber informasi, komunikasi, serta media elektronik lainnya.

Strategi guru menurut Yuangga \& Sunarsi, (2020) pendekatan untuk pembelajaran terhadap pelajaran secara daring, yaitu: (a) Memperkuat interaksi antara guru dan murid (b) Pemanfaatan interaksi antar 
mahasiswa atau murid. (c) Merencanakan kuis online.

Para guru harus kreatif dan inovatif saat memakai e-learning, serta harus mempunyai sikap kritis dalam membuat materi pembelajaran. Guru harus bisa memposisikan murid (peserta didik) tidak sebagai "pendengar" saja atau "penonton", tetapi harus mampu mendorong murid (peserta didik) agar melakukan interaksi, saling berbicara, kerja sama dalam mengembangkan ilmu pengetahuan Pusvyta Sari (2015)". Dari Mahnun (2012) "Media" dalam bahasa latin adalah "medium" yang mempunyai arti "pengantar" atau "perantara". Hal lain yang menghambat kegiatan pembelajaran jarak jauh yaitu mengenai kecepatan serta ketepatan transfer modul dari pusat data kepada peserta daring di tempat terpencil atau pedalaman.

Komunikasi dua arah dalam pengajaran sangat perlu dilakukan dimana ada dialog antara guru (pengajar) dengan siswa atau pembelajar (peserta didik) (Nur Inah, 2015).

Sistem teknologi informasi dimasa mendatang tidak hanya berfungsi sebagai pendukung kinerja pendidikan tetapi akan menjadi senjata utama keberhasilan dalam bidang pendidikan agar mampu bersaing di dalam dunia global Budiman (2012).

Tugas utama guru sebagai pendidik profesional, yaitu mengajar, melatih, membimbing, menilai murid pada tempat pendidikan anak usia dini (TK), sekolah dasar (SD), dan sekolah menengah pertama (SMP) dan menengah atas (SMA). Guru disaat melakukan kegiatan profesionalnya, memiliki kewajiban merancang materi belajar, melakukan kegiatan belajar mengajar yang kualitas serta bermutu, memberi nilai, serta memonitoring hasil pengajaran Handayani \& Dewi (2020)

Saat pandemi covid-19 sekarang ini, Mendikbud nomor 36962, yaitu surat edaran mengenai pembelajaran secara online dan bekerja di rumah (WFH atau work from home) sebagai upaya mencegah perluasan virus covid-19 kemendikbud, (2020).

Guru mendapatkan edaran surat dari menPAN-RB tahun 2020 Nomor 34 (MENPANRB, 2020), untuk melaksanakan tugas dinas di rumah disesuaikan dengan ASN atau sistem kerja aparatur sipil negara sebagai usaha melawan, perluasan virus covid sekitar lingkungan instansi (dinas) pemerintah. PJJ saat ini merupakan solusi terbaik agar tetap bisa melakukan pendidikan pengajaran dengan tetap mencegah penularan covid-19 (Rohmah, 2020).
Supaya murid atau peserta didik bisa mendapatkan semua tujuan pembelajaran yang telah dirancang, maka diperlukan sebuah media pembelajaran yang secara fisik ataupun teknis disaat kegiatan belajar-mengajar bisa membantu guru dan mempermudah ketika penyampaian materi pembelajaran kepada murid (peserta didik) Tafonao (2018). Media interaksi yaitu media yang memungkinkan untuk berinteraksi Setiadi (2014). Media pembelajaran memiliki tiga fungsi yang saling terhubung (terintegrasi), yaitu stimulasi untuk menumbuhkan minat atau ketertarikan saat mendalami pelajaran, mediasi penghubung bagi murid (peserta didik) dan guru (pengajar), informasi yang menampilkan penjelasan dari guru Wisnu Nugroho Aji (2020)".

Menurut Pelangi (2020) aplikasi berbasis online yang menyediakan design menarik untuk keperluan pendidikan salah satunya yaitu canva. Canva adalah salah satu alat bantu dengan platform design yang kolaboratif untuk mengembangkan kreativitas, keterampilan, dalam membuat pembelajaran visual, sehingga komunikasi menjadi menyenangkan dan lebih mudah.

SMK Muhammadiyah 7 Tebet Timur Jakarta yang berlokasi di Tebet Jakarta Selatan, Jalan Tebet timur raya No. 565 merupakan sebuah Lembaga Pendidikan Formal yang berbasis Karakter Islami modern berkemajuan, dan siap bekerja sama dengan siapapun untuk membangun kehidupan anak bangsa dan membantu mereka mencapai cita cita serta memotivasi mereka untuk terus belajar mengembangkan kepribadian dan kemampuan (Ridwan, n.d.). SMK Muhammadiyah 7 Jakarta masuk dalam zona merah dalam penyebaran virus covid-19, sehingga gubernur DKI Jakarta segera melakukan PSBB atau PPKM darurat (Pemberlakukan Pembatasan Kegiatan Masyarakat) dengan tenggang waktu lama. Oleh sebab itu, diperlukan sebuah media atau alat pembelajaran jarak jauh yang efektif, dimana media tersebut harus mudah dipelajari bagi para guru SMA/SMK. Dari hasil survei tim pengabdian ke sekolah SMK Muhammadiyah 7 Jakarta, maka kendala yang ditemui dilapangan adalah, Guru perlu mengembangkan keterampilan dalam penggunaan media Canva sebagai pendukung pembelajaran jarak jauh yang menarik dan dinamis. Tujuan pengabdian ini adalah untuk membantu para guru yang belum bisa menggunakan aplikasi canva, bahkan ada yang belum mengetahui apa itu aplikasi canva, dan selama ini masih melakukan pembelajaran jarak jauh dengan menggunakan cara konvensional membaca buku tanpa ada aplikasi penunjang 
pembelajaran lainnya. Hal ini menyebabkan siswa merasa bosan atau tidak fokus, apalagi dengan kondisi pembelajaran jarak jauh saat ini. Sangat diharapkan dengan adanya pelatihan ini maka guru menjadi lebih kreatif dan inovatif saat nanti membuat materi pembelajaran disesuaikan dengan mata pelajaran masing-masing guru tersebut.

\section{METODE}

Kegiatan pengabdian ini berupa pemanfaatan aplikasi dalam mendukung kegiatan pembelajaran jarak jauh kepada guruguru SMK Muhammadiyah 7 Jakarta. Pengabdian masyarakat ini dilakukan dalam waktu tiga bulan, peserta pelatihan ini sebanyak kurang lebih sepuluh orang guru. Saat pengabdian masyarakat dilakukan Kota Jakarta sedang dilakukan WFH, oleh karena itu pelatihan dilakukan secara daring atau online.

Pengabdian ini dilakukan dalam bentuk pemberian materi training, yaitu:

1. Training 1: memberikan pengertian mengenai cara pemanfaatan kelas virtual menggunakan canva, google classroom, pengelolaan kelas virtual seperti mengunggah tugas/soal, serta memberikan nilai pada tugas/soal yang telah dikumpulkan melalui kelas virtual tersebut.

2. Training 2: pemahaman tentang pemanfaatan canva, zoom meeting untuk menggantikan belajar mengajar secara tatap muka di kelas, pengelolaan zoom meeting secara otomatis dan terjadwal.

Adapun langkah-langkah kegiatan yang tim lakukan untuk pengabdian ini, yaitu:

1. Persiapan

Melakukan survey, pemantauan, pemantapan, serta penentuan lokasi pengabdian. Berkomunikasi dengan mitra hingga mengurus surat kerjasama, yaitu kepala sekolah SMK Muhammadiyah 7 Jakarta.

2. Pelaksanaan

Pelaksanaan kegiatan dilakukan selama satu minggu. Paparan langkah kegiatan yang dilakukan adalah pemahaman tentang pemanfaatan kelas virtual menggunakan google classroom, pengelolaan kelas virtual seperti mengunggah tugas/soal, serta memberikan nilai pada tugas/soal yang telah dikumpulkan melalui kelas virtual tersebut. Setelah itu memberikan pemahaman tentang pemanfaatan zoom meeting untuk menggantikan belajar mengajar secara tatap muka di kelas, pengelolaan zoom meeting secara otomatis dan terjadwal.

\section{Evaluasi}

Evaluasi dari kegiatan pengabdian ini yaitu dengan melakukan sesi tanya jawab dengan guru-guru peserta kegiatan, dan kuesioner. Evaluasi ini dengan menggunakan metode skala likert. Rumus dari Skala likert $=\mathrm{Tr}$ * $\mathrm{Pm}$ (Suasapha, 2020). Penjelasan :

$\mathrm{Tr}=$ Jumlah total penjawab yang memilih

$\mathrm{Pm}=$ Jumlah angka yang dipilih likert.

Skor perhitungan :

$A=$ Nilai paling tinggi dari likert * Jumlah jawab.

$B=$ Nilai paling rendah likert * Jumlah jawab.

Rumus index merupakan total skor dibagi B dikalikan nilai seratus.

Index $(\%)=\frac{\text { Total skor }}{B} * 100$

Adapun keterangan interval seperti tabel 1 , berdasarkan persepsi penulis ditinjau dari kepuasan peserta dalam mengikuti pelatihan, kecakapan penyampaian materi oleh narasumber, dan hasil tanya jawab yang dilakukan oleh peserta pelatihan.

Tabel 1. Interval Persepsi Pensentase Penilaian Skala Likert

\begin{tabular}{ll}
\hline \multicolumn{2}{c}{ Interval \% } \\
\hline $0-24.9 \%$ & Sangat tidak puas \\
\hline $25-49.9 \%$ & Kurang puas \\
\hline $50-74.9 \%$ & Puas \\
\hline $75-100 \%$ & Sangat puas \\
\hline
\end{tabular}

\section{HASIL DAN PEMBAHASAN}

Kegiatan pengabdian masyarakat sudah terlaksana dengan baik walaupun di masa pandemi, pelaksanaan kegiatan tetap memberikan pelatihan terbaik bagi para peserta pelatihan. Pelaksanaan kegiataan menggunakan aplikasi zoom meeting, dengan dilakukan dua sesi, yaitu sesi pertama adalah memberikan pemahaman secara teori mengenai modul pembelajaran dilanjutkan dengan praktik penggunaan aplikasi canva dalam menunjang proses pembelajaran. Setelah itu sesi kedua adalah memberikan pelatihan penggunaan zoom meeting dan google classroom. Pelatihan ini bekerjasama dengan SMK Muhammadiyah 7 Jakarta. Dan kegiatan ini berjudul, "Pelatihan Pemanfaatan Aplikasi Canva Dalam Mendukung Pembelajaran Jarak Jauh". Secara garis besarnya kegiatan pengabdian program kemitraan masyarakat memiliki empat bagian, berikut:

1) Tercapainya tujuan dari pelatihan di pengabdian masyarakat dan tersampaikannya semua target materi. Tujuan pelatihan untuk pengabdian kepada masyarakat adalah menjadi bentuk 
tanggung jawab sosial dan peran serta dosen di bidang pendidikan. Dosen mempunyai tanggung jawab sosial diantaranya membantu masyarakat khususnya bagi guru dalam melaksanakan pembelajaran jarak jauh. Materi yang diberikan mencakup:

a. Konsep dasar modul pembelajaran

b. Karakteristik modul pembelajaran

c. Tujuan penulisan modul

2) Ketercapaian jumlah peserta pelatihan. Pendaftaran dilakukan secara pemilihan langsung dari sekian guru untuk mengikuti pelatihan. Beragam guru dengan basic yang bermacam macam. Kegiatan ini dihadiri 7 peserta.

3) Peserta begitu antusias dalam bertanya. Dengan jumlah guru peserta yang minim, tidak mengurangi semangat para peserta pelatihan selama proses pelatihan berlangsung.

4) Para peserta mampu memahami materi yang diberikan. Pelaksanaan kegiatan ini secara daring, dimana tentunya penggunaan perangkat tiap peserta memiliki spesifikasi yang beragam dalam menunjang proses pelatihan. Namun selama proses berlangsung, semua peserta memiliki perangkat yang sangat memadai sehingga penyampaian materi dapat dilakukan dengan maksimal.

Tim juga mengevaluasi kegiatan PKM selain dengan empat komponen di atas, yaitu dengan memberikan link kuesioner kepada semua peserta menggunakan google form. Melihat di tabel data 2, merupakan perhitungan dengan skala likert, dari tujuh pertanyaan. Skala likert digunakan untuk mengukur skala positif dari pertanyaan positif, dan mengukur skala negatif dari pertanyaan negatif. Dengan menggunakan rumus indeks persentase adalah jumlah keseluruhan penjawab yang terpilih dikali pilihan nilai likert.

Tabel 2. Pertanyaan \& Presentase Hasil skala likert.

$\begin{array}{ccc}\text { No. } & \text { Pernyataan } & \% \\ \mathbf{1} & \begin{array}{c}\text { Penyampaian materi oleh narasumber } \\ \text { sangat memuaskan }\end{array} & 92,86 \\ \mathbf{2} & \begin{array}{c}\text { Jawaban dari narasumber pada sesi } \\ \text { tanya-jawab sangat memuaskan }\end{array} & 89,29 \\ \mathbf{3} & \text { Tepat waktu selama acara } \\ & \text { berlangsung (ketepatan sangat baik) } & 92,86 \\ \mathbf{4} & \text { Kegiatan sangat interaktif } \\ \mathbf{5} & \text { Pengetahuan setelah pelatihan } & 85,71 \\ \mathbf{6} & \text { Kualitas audio \& visual sangat baik } & 78,57 \\ \mathbf{7} & \text { Kegiatan pelatihan ini sangat } & 78,57 \\ & \text { bermanfaat } & 82,14\end{array}$

Tabel 3 Pertanyaan dan persentase hasil perhitungan dengan skala likert.

\begin{tabular}{|c|c|c|c|c|c|c|c|c|c|c|c|}
\hline \multicolumn{12}{|c|}{ Perhitungan Kuesioner Sesudah Pengabdian Masyarakat } \\
\hline \multicolumn{12}{|c|}{ Media Daring Dengan Total Peserta : 7 orang } \\
\hline \multirow{2}{*}{ No } & \multicolumn{4}{|c|}{ Skor } & \multirow{2}{*}{$\begin{array}{c}\mathrm{N}- \\
\mathrm{Max}\end{array}$} & \multicolumn{4}{|c|}{ Jumlah Skor } & \multirow{2}{*}{ Jml } & \multirow{2}{*}{$(\%)$} \\
\hline & 1 & 2 & 3 & 4 & & 1 & 2 & 3 & 4 & & \\
\hline 1 & 0 & 0 & 2 & 5 & \multirow{7}{*}{28} & 0 & 0 & 6 & 20 & 26 & 92,86 \\
\hline 2 & 0 & 0 & 3 & 4 & & 0 & 0 & 9 & 16 & 25 & 89,29 \\
\hline 3 & 0 & 0 & 2 & 5 & & 0 & 0 & 6 & 20 & 26 & 92,86 \\
\hline 4 & 0 & 1 & 2 & 4 & & 0 & 2 & 6 & 16 & 24 & 85,71 \\
\hline 5 & 0 & 1 & 4 & 2 & & 0 & 2 & 12 & 8 & 22 & 78,57 \\
\hline 6 & 0 & 1 & 4 & 2 & & 0 & 2 & 12 & 8 & 22 & 78,57 \\
\hline 7 & 0 & 1 & 3 & 3 & & 0 & 2 & 9 & 12 & 23 & 82,14 \\
\hline \multicolumn{11}{|c|}{ Jumlah Presentasi } & 600,00 \\
\hline \multicolumn{11}{|c|}{ Rerata Total (\%) } & 85,71 \\
\hline
\end{tabular}

Penjelasan tabel 3, bahwa peserta merasa penyampain materi dari narasumber sangat memuaskan dengan nilai persentase $92,86 \%$, foto kegiatan penyampaian materi dapat dilihat di gambar 1. Hasil tanya jawab peserta nampak antusias untuk mengenali kegunaan dari aplikasi canva, gambar praktek dapat dilihat di gambar 2. Kualitas audio dan visual saat penyampaian materi melalui daring didapatkan persentasi $78.57 \%$ berarti dinilai baik. Total hasil dari pelatihan ini adalah $85,71 \%$ dapat dikatakan sangat memuaskan peserta pelatihan.

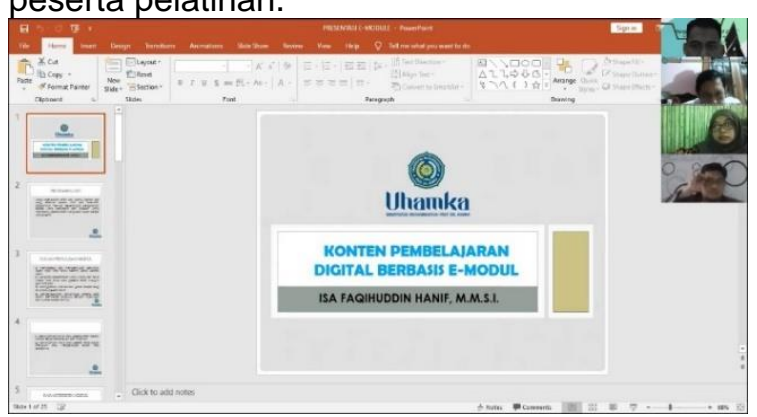

Gambar 1. Pemahaman Konsep

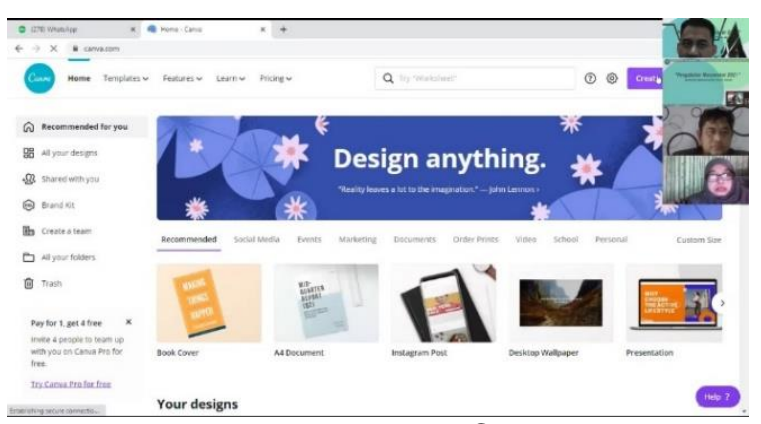

Gambar 2. Praktik Canva

Gambar 3 merupakan hasil produksi desain dari pelatihan yang telah dilakukan. Peserta mengungkapkan kegiatan pelatihan ini sangat bermanfaat dengan nilai kuesioner $82.14 \%$. 
Pengabdian ini tujuannya lebih terfokus kepada menambah keterampilan kepada para guru dalam penggunakan aplikasi canva untuk menunjang pembelajaran jarak jauh, agar siswa merasa lebih tertarik dengan mata pelajaran yang diberikan. Berbeda dengan pengabdian oleh (Sholeh et al., 2020) ini bertujuan penggunakan aplikasi canva untuk alat media promosi bagi para pelaku UMKM, di mana nantinya dapat menggunakan templatetamplate, logo yang tersedia sebagai pembuatan poster, flayer, logo, info grafis, dsb. Pengabdian lain oleh (Purwati \& Perdanawanti, 2019) juga hampir sama dengan pengabdian (Sholeh et al., 2020) yaitu melakukan pengabdian pelatihan menggunakan aplikasi canva bertujuan untuk membantu komunitas ibu-ibu dalam pembuatan flyer, sertifikat, kartu ucapan, dan design produk.

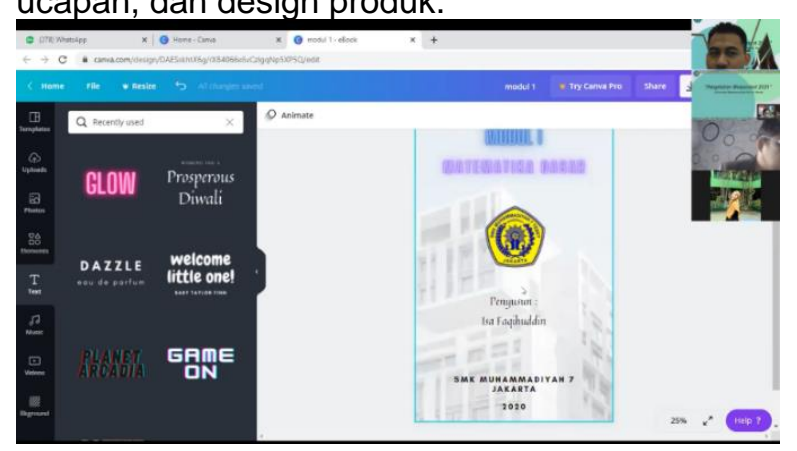

Gambar 3. Produksi desain

\section{SIMPULAN DAN SARAN}

Pengembangan modul dan konten pembelajaran di masa pandemi, dan penerapan pembelajaran jarak jauh harus menjadi perhatian. Bagaimana menerapkan pembelajaran yang sifatnya menarik dan dinamis, sehingga murid (peserta didik) tidak lekas merasa bosan dan lebih mudah memahami materi sama halnya ketika pelaksanaan pembelajaran dilakukan secara offline. Disamping itu, kegiatan ini dapat mengembangkan kompetensi guru dalam penggunaan aplikasi Canva yang tentunya dapat menunjang proses belajar mengajar. Pelaksanaan dilakukan secara daring, dimaksimalkan agar tujuan dari pelatihan ini dapat tercapai dengan maksimal dan tentunya para peserta diharapkan dapat mengimplementasikan dari hasil kegiatan yang telah diikuti.

Saran, pelatihan ini perlu dilakukan lebih terfokus sesuai dengan matapelajaran dari tiap guru di sekolah, perlu ditambahkan pelatihan animasi untuk lebih menambah minat dari siswa.

\section{UCAPAN TERIMAKASIH}

Kepada (Uhamka) Universitas

Muhammadiyah Prof. Dr. Hamka, melalui
LPPM Tim pengabdian masyarakat mengucapkan Terima kasih karena telah menyelenggarakan serta memberikan pendanaan terhadap pelaksanaan pengabdian masyarakat ini secara keseluruhan. Dan juga terima kasih kepada SMK 7 Muhammadiyah Jakarta yang telah bersedia menjadi tempat pengabdian tim pkm.

\section{DAFTAR RUJUKAN}

Budiman, H. (2012). PERAN TEKNOLOGI INFORMASI DAN KOMUNIKASI DALAM PENDIDIKAN. Al-Tadzkiyyah: Jurnal Pendidikan Islam, 8, 75-83. https://media.neliti.com/media/publication s/177430-ID-peran-teknologi-informasidan-komunikasi.pdf

Handayani, S. L., \& Dewi, T. U. (2020). Pelatihan Penulisan Karya IImiah Bagi Guru-Guru Sekolah Dasar Untuk Meningkatkan Kompetensi Profesionalisme Guru Fungsional Guru dan Angka membuat Karya Tulis IImiah. Aksiologiya: Jurnal Pengabdian Kepada Masyarakat, 4(1).

Hasan, F. N., Hanif, I. F., \& Meitova, R. S. (2020). Implementasi nilai-nilai al-islam di kehidupan sehari-hari, studi kasus mahasiswa fakultas teknik universitas muhammadiyah prof. dr. hamka. Jurnal Pendidikan Islam, 1-16.

kemendikbud. (2020). Surat Edaran Menteri Pendidikan dan Kebudayaan Republik Indonesia Nomor 36962/MPK.A/HK/2020. Mendikbud RI, 1-2. https://www.kemdikbud.go.id/main/index. php/files/download/c5d9f0ec9ff40c6

Mahnun, N. (2012). Media Pembelajaran (Kajian terhadap Langkah-langkah Pemilihan Media dan Implementasinya dalam Pembelajaran). An-Nida', 37(1), 27-35.

MENPANRB. (2020). Surat Edaran MENPANRB Nomor 34 Tahun 2020 Tentang Penyesuaian Sistem Kerja Aparatur Sipil. 1-2.

Nur Inah, E. (2015). PERAN KOMUNIKASI DALAM INTERAKSI GURU DAN SISWA. Al-Ta'dib, 8(2), 150-167.

Pelangi, G. (2020). PEMANFAATAN APLIKASI CANVA SEBAGAI MEDIA PEMBELAJARAN BAHASA DAN SASTRA INDONESIA JENJANG SMA/MA. Jurnal Sasindo Unpam, 8(2), 79-96.

Purwati, Y., \& Perdanawanti, L. (2019). Pelatihan Desain Menggunakan Aplikasi Canva. Jurnal Pengabdian Mitra Masyarakat (JPMM) Vol., 1(1), 42-51.

Pusvyta Sari. (2015). Memotivasi Belajar 
Dengan Menggunakan E-Learning. Ummul Quro, 6(Jurnal Ummul Qura Vol VI, No 2, September 2015), 20-35. http://ejournal.kopertais4.or.id/index.php/ qura/issue/view/531

Ridwan, M. (n.d.). Profil SMA Muhammadiyah 5 Jakarta.

Rohmah, N. (2020). Implementasi Pembelajaran Jarak Jauh pada Masa Pandemi Covid-19. Awwaliyah: PGMI, 3(2), 89-95.

Setiadi, A. (2014). Pemanfaatan media sosial untuk efektifitas komunikasi. Jurnal IImiah Matrik, 16(1).

Sholeh, M., Rachmawati, R. Y., \& Susanti, E. (2020). Penggunaan Aplikasi Canva Untuk Membuat Konten Gambar Pada Media Sosial Sebagai Upaya Mempromosikan Hasil Produk Ukm. SELAPARANG Jurnal Pengabdian Masyarakat Berkemajuan, 4(1), 430. https://doi.org/10.31764/jpmb.v4i1.2983

Suasapha, A. H. (2020). Skala Likert Untuk Penelitian Pariwisata; Beberapa Catatan Untuk Menyusunnya Dengan Baik. Jurnal Kepariwisataan, 19(1), 26-37. https://doi.org/10.52352/jpar.v19i1.407

Tafonao, T. (2018). Peranan Media Pembelajaran Dalam Meningkatkan Minat Belajar Mahasiswa. Jurnal Komunikasi Pendidikan, 2(2), 103. https://doi.org/10.32585/jkp.v2i2.113

Wisnu Nugroho Aji, D. B. P. S. (2020). APLIKASI TIK TOK SEBAGAI MEDIA PEMBELAJARAN KETERAMPILAN BERSASTRA. Metafora, VI(2), 8-29.

Yuangga, K. D., \& Sunarsi, D. (2020). PENGEMBANGAN MEDIA DAN STRATEGI PEMBELAJARAN UNTUK MENGATASI PERMASALAHAN PEMBELAJARAN JARAK JAUH DI PANDEMI COVID- 19. (Kharisma Dan Denok, 2020 ), 4(3), 51-58. 